\title{
Individually-Differentiated Approach to the Educational Process Organization for Disabled People
}

Tatiana V. Lavrienko and Tatiana V. Pen*

In this article the authors analyzed the educational process regarding the disabled people; the research is focused on the Siberian Federal University program "Profession and Health".

The analysis comprised the pedagogical experiment, observations, testing, conversations, dialogues between a student and a teacher, the self-assessment and monitoring of pupils (students), the summary of the pedagogical experience.

The array of methods and forms has been developed from the results. These methods enable the realization of the individual and differential approach in the educational process, namely dialogical methods, individual consultations, the permanent and all-comprising test control and self-diagnostic methods.

It has been revealed that vital prerequisites for the efficient learning process are: the knowledge of psychological and pedagogical features of the cognitive activity of students, the emotional and positive attitude in the interaction between the teacher and the student, the use of the special complex of the educational forms and methods, which correspond to the needs of people with disabilities.

Keywords: disabled people; educational process; pedagogical experiment; individually-differentiated approach; dialogical methods; self-diagnostic methods.

DOI: 10.17516/1997-1370-0019.

Research area: pedagogy.

\section{Introduction}

Disabled people require specific approach specified by the necessity of help in personal development, assertiveness and social adaptability

The effective work with listener of preparatory department with musculoskeletal system diseases is possible with realization of individually-differentiated education process. The main principles of selecting the methods, forms and means for realization of this approach in educational process are the following: taking into account the general and individual traits of listener; the preliminary adaptation of listener to high school education through the continuity of learning; the increase of pupils' subjectivity;

(C) Siberian Federal University. All rights reserved

* Corresponding author E-mail address: silp167@inbox.ru 
the influence on the listeners' personal development through the humanistic means of communication.

Following S.A. Smirnov's example we adhere to such educational doctrine as: "The method of education is the way of organizing the educational and informative activity of the student from the first tasks, considering the levels of informative activity and the results for the achievement of didactic purposes".

Bearing in mind Yu.K. Babanskii's ideas about classification of the educational methods, we allocate three main methodical groups, such as: the organization, the incentive and the control which track the educational activity efficiency.

\section{Methods}

The organizational constituent of educational methods consists of observing the practical educational abilities and accumulation of the training experience in the activities which are possible in the real educational practice. There are three methods of realization: the exercises, laboratory and practice work. Generally, we used the exercises. Applying exercises is rather difficult, multivariate and depends on the age, on the progress, on the preparedness to studying and on the students' moods. Usually the groups of exercises are distinguished by the degree of student's independence, by the nature of educational activity. In our research the practical exercises were widely used for fixing methods of mathematical operations.

Conversation and repetition are used for saving new knowledge in a long-term memory. Their application has its own specificity. The usage of already studied material as a basis for forming new concepts and educational abilities was meant for learning a new theme. The creation of a network of mathematical operations resulted in students' understanding of mathematics and uniform multidimensional knowledge.
Recently more and more attention is paid to the interactive methods of organizing students' communication. The dialogic communication between each other and with the teacher lies at the heart of these methods. The following methods were used: the development of the elementary norms of conversation, the mutual check, the cooperative tasks, the joint finding of the best decisions, the temporary work in groups, the creation of joint experience, the organization of the students' work - consultations, discussions.

\section{Discussion}

Under the problem of educational process efficiency we understand that the modern education process is possible only if the student takes subjective position. That is why we devoted serious attention to the second group of the educational methods, namely the method of the students' promotion in the educational and informative activity. It includes: the emotional promotion, the development of the educational interest, the formation of responsibility and obligation, the development of creative abilities and students' personal qualities. The emotional stimulation occurs when situation of the success in education is specially created, when the promotion and censure are applied, when the games and game forms are used for organizing education activity and for identifying the perspective system. The development of interest occurs in the following conditions: the formation of the readiness to acquire the studied material, the forming of the studied material around the game story, the stimulation with the entertaining content, the creative search. We used all of these emotional methods of stimulation and developing the listener's interest. The support of the knowledge and any cognitive activity of a listener, apart from emotional involvement, led to the establishing positive relations between listeners and us; and 
all of these made the learning process more efficient.

Training in a higher educational institution is closely connected with social interaction. A serious negative effect is a state of emotional discomfort, fear, apprehension and anxiety about social situations and estimates of other people. These effects can have a serious impact on the process of social and emotional adjustment and quality of the students' life, when they have such a thing as social anxiety. Very often due to the increased anxiety the student really is not capable to act effectively when other people are around. Avoiding situations of human contact, such students deprive themselves of the opportunity to develop their social skills and to be convinced that they are capable to interact successfully.

The high level of anxiety of our listeners can have destructive impact on their learning activities. The more effective pedagogical form is creation of the cooperation atmosphere. For any person the main moment of communication is to understand the people's feelings. That is why sarcastic tone was void for the students and their self-confidence. The main way of information, which we used, was "I-message". In "I- message" the teacher sincerely describes his/her feelings (disappoint-ment, anxiety, weariness and etc.) not causing student's hostility and threat. Unlike "You-message", "I-message" encourages students to demonstrate sensitivity and help teachers in their work. Herewith probability of conflict situation is reduced; psychological intensity in relation between students and teachers subsides.

Besides, when students showed their emotions we used special technique of "nondirective" direction. This technique includes the simple accentuating statements; these are "Yes, I see", "Yes, I understand" in the corresponding tone, when next teacher's words reflect student's emotions. These help students to understand their emotional state, then the teacher requests student to rephrase their words thereby the teacher demonstrates his/her ability to listen carefully and understand the student. In addition to these approaches, we used a number of techniques which have instrumental and applied meaning, and which let teachers encourage student for the next discussion and learning, handling problems: the structuring statements, the direct questions, the minimal encouragement for the continuing conversation, non-directive suggestive remarks and straight questions, fostering student to choose the theme for discussion.

The structuring statements preceded the conversation in the certain limits. ("If we talk about this problem we can find the decision, which would satisfy both of us. Can you tell me your point of view? I would like to listen"). The direct questions demonstrate understanding and specify the interlocutor position ("I'm not sure that I understood you correctly. Do you suppose that $<\ldots>$ ? Can you give me the correct example? What do you mean when you say that...")? The minimal encouragement for continuing the conversation allows interlocutor to speak out (“Really? And what's next? So what?"). Nondirective suggestive remarks and open questions invite interlocutor to express the opinion ("Can you tell me about this more in detail", "What could you do otherwise?", "How are the things since I met you last time?"). It is implied that the student is to choose the theme of conversation and discussion ("What will be our discussion today?", "Do you think it is the problem?", "And what do you think about these?").

The establishment of good, harmonious relations, which are based on the psychological support of the student by the teacher, the respect for the legal rights of the emerging personality are necessary for the healthy development, because the inner self in period of the rapid growth of a young body is characterized by the extreme volatility and sharp dramatic collisions. 
The described approaches remain only external, formally adopted and formally applied manipulative techniques of the communication, unless they are based on the deep sincere interest of the person in a teenager or in the teenager's aspiration to learn and understand their individuality. We deliberately studied and supported not only individual qualities of our listeners and their achievement, but also their responsible attitude, the intensity of their efforts. The methods of formation of the student's responsibility and obligation are: the formation of the personal significance of the education, the presentation of the training requirements and the formulation of the educational purposes, the operational and total control. All of these methods are relevant for the research, but we paid the greatest attention to development of the personal significance concerning the education of listeners with musculoskeletal system diseases (especially the scoliosis patients). The teenager stops being someone who depends and accepts care of the people around them and adults, who care about their future. Now this teenager is becoming someone who thinks about their prospects, who is an active builder of their professional life and is a milestone of attitude. Among other methods of stimulation we would like to mention the problem of creating the challenging situation, which activates the listener's mind.

The third group - the methods of control and diagnosis of the learning efficiency, the social and psychological development of student - is rather diverse. We used them widely, giving the considerable attention to testing, which is the important moment of educational process with individually-differentiated approach to the listeners with scoliosis. The role of this control method was determined by two factors: firstly, the significance of testing as a control method of the level and dynamics of students' knowledge; secondly, no less important, as a means to prepare the listener for the transition from school to university system.

For the educator the main components of teaching students to work independently with tests were objective, pithy and reflexive. We identified the main objectives of this activity for the teacher. They are forming the listener's ability to do the main type of check tests; the inculcation of diagnostics and self-diagnostics skills with regard to the results of their implementation; forming the ability to identify unlearned and uncovered earlier material by the diagnostics results, and also the ability to create and do the learning tasks; the organization of the student interaction in this process. The content of the activity was determined by the above-mentioned goals and was concretized taking into account features of each studied module. We also took into consideration the didactic content; the individual characteristics of a particular student; the level of acquirement according to their general educational abilities, the specific mathematical tools and the exact knowledge and skills. Under the activity component we understand the content actualization in the act of interaction between the student and the teacher. Our work of translation of the content and providing conditions for students' active perception is determined by the pedagogical experience, both didactic and educational; the personal characteristics; the complete coverage of all sets of the students' personal characteristics; the nature of our interaction. The reflexive component of our activity is directed at the process of forming and realizing all considered above active components.

For the student the main methods in the educational process with regard to the selfdiagnosis and self-correction skills were abilities to plan their own activity; to define the goals of the work, stages, areas, the time required for the task completion; to control the current and final results. 


\section{Conclusion}

In such a way, the analysis of the methods and forms of organization and realization the educational process for the people with musculoskeletal system diseases allowed us to draw the following conclusions: the selection of the methods and forms for the study is necessary to perform them in accordance with the objectives and contents of the listeners' training; during the selection of the methods and forms for teaching students mathematics one should take into account the peculiarities of such children. These are the health regulations; the methods and forms of education which should maintain the continuity in the school and university systems of students' preparation.

\title{
References
}

Krasnova, V.V., Kholmogorova, A.B. (2011). Sotsial'naia trevozhnost' i ee sviaz' s emotsional'noi dezadaptatsiei, urovnem stressa i kachestvom interpersonal'nykh otnoshenii u studentov [Social anxiety and its connection to the emotional disadaptation, stress levels and the quality of interpersonal relationships among students], In Voprosy Psikhologii [Issues of Psychology], (3), 49-58.

Sobkin, V.S., Kalashnikova, E.A. (2013). Uchenik osnovnoi shkoly: otnoshenie k dopolnitel'nomu obrazovaniiu [Secondary school student - attitude towards the additional education], In Voprosy Psikhologii [Issues of Psychology], 4, 16-26.

Vartanova, I.I. (2012). Senior pupil's personality: motivation and values, In Voprosy Psikhologii [Issues of Psychology], 3, 3-11. doi: 000088388800072

Vartanova, I.I. (2010). Razvitie uchebnoi motivatsii i tsennostei starshikh shkol'nikov [The development of senior high school students' motivation and values]. Psychological journal,4, available at: http://www. psyanima//ru

Pidkasistyi, P.I. (2011). Pedagogika i psikhologiia [Pedagogy and psychology]. Moscow, Iurait, $602 \mathrm{p}$.

Vygotskii, L.S. (2008). Pedagogicheskaia psikhologiia [Pedagogical psychology]. Moscow, AST, $420 \mathrm{p}$.

Bim-Bad, B.M. (2008). Pedagogicheskii entsiklopedicheskii slovar [Pedagogical encyclopedic dictionary]. Moscow, Drofa: Great Russian encyclopedia, 528 p.

\section{Индивидуально-дифференцированный подход при организации образовательного процесса Для лиц с ограниченными возможностями здоровья}

\author{
Т.В. Лавриенко, Т.В. Пен \\ Сибирский федеральный университет \\ Россия, 660041, Красноярск, пр. Свободный, 79
}

В статье проводится анализ образовательного проиесса, реализуемого для лии с ограниченными возможностями здоровья, обучающихся по программе «Профессия и здоровье» в Сибирском федеральном университете. 
Для решения поставленных задач проводились и анализировались: педагогический эксперимент, наблюдение, тестирование, беседы, диалогические общения учащихся между собой и с педагогом, самооценка и самоконтроль учащихся (студентов), изучение и обобщение педагогического опыта.

В результате исследования разработан комплекс методов и форм обучения, обеспечивающий реализачию индивидуально-дифференциального подхода в образовательном процессе: диалогические методы, индивидуальные консультации, перманентный и тотальный тестовый контроль, способы самодиагностики.

Установлено, что определяющими условиями эффективного прочесса обучения являются: знание психолого-педагогических особенностей познавательной деятельности учащихся, наличие эмоционально-положительного отношения во взаимодействии педагога и студента, использование специального комплекса форм и методов обучения, отражающего особенности лии с ограниченными возможностями здоровья.

Ключевые слова: лица с ограниченныли возможностями здоровья, образовательный проиесс, педагогический эксперимент, индивидуально-дифференциальный подход, диалогические методы, самодиагностика.

Научная специальность: 13.00.00 - педагогические науки. 